\title{
KEDUDUKAN DAN PERAN ADVOKAT DALAM PROSES PENYELESAIAN PERKARA PIDANA
}

\author{
Achmad Rifai \\ (Dosen Fakultas Hukum Universitas Madura)
}

\begin{abstract}
:
The position of advocates (lawyers) as a law advisors in any process of investigation must be central, in terms of that they must place themselves as the representatives of the suspect to get the an appropriate rights. It is mistaken that an advocate acts from the side of attorney as general prosecutor. In the course of law enforcement, it has been fairly set up either the roles of attorney representing the victim or the demanded person, the suspect. During the process of investigation, the investigator (attorney or police officer) is standing for the victim, nevertheless the suspects are represented by an advocate as their law advisor. In the level of prosecution, the victim must be put up with an attorney as the general prosecutor; the advocate, as the law advisor, represents the suspect.
\end{abstract}

Keywords:

advokad, penasihat hukum, bantuan hukum, penuntut umum, dan terdakwa,

\section{Pendahuluan}

Istilah bantuan hukum merupakan hal yang baru bagi bangsa Indonesia. Masyarakat baru mengenal dan mendengarnya pada sekitar tahun 1970-an. ${ }^{1}$ Aliran lembaga bantuan hukum yang berkembang di negara Indonesia pada hakikatnya tidak luput dari arus perkembangan bantuan hukum yang terdapat pada negaranegara yang sudah maju. Di dunia Barat pada umumnya, pengertian bantuan hukum mempunyai ciri dalam istilah yang berbeda. Ada 3 (tiga) jenis bantuan hukum yakni: Pertama, legal aid, yang berarti

1Frans Hendra Winarta, Advokat Indonesia Citra, Idealisme dan Kepribadian, (Jakarta: Pustaka Sinar Harapan, 1995), hlm.10 
pemberian jasa di bidang hukum kepada seseorang yang terlibat dalam suatu kasus atau perkara pemberian jasa bantuan hukum dengan cuma-cuma. Bantuan jasa hukum dalam legal aid lebih dikhususkan bagi yang tidak mampu dalam lapisan masyarakat miskin. Dengan demikian motivasi utama dalam konsep legal aid adalah menegakkan hukum dengan jalan membela kepentingan dan hak asasi rakyat kecil yang miskin dan buta hukum. ${ }^{2}$

Kedua, legal assistance, yang mengandung pengertian lebih luas dari legal aid. Karena pada legal assistance, di samping mengandung makna dan tujuan memberi jasa bantuan hukum, lebih dekat dengan pengertian yang kita kenal dengan profesi advokat, yang memberi bantuan baik kepada mereka yang mampu membayar prestasi, maupun pemberian bantuan kepada rakyat yang miskin secara cumacuma. $^{3}$

Ketiga, legal service, yang dalam bahasa Indonesia diterjemahkan sebagai "pelayanan hukum". Pada umumnya orang lebih cenderung memberi pengertian yang lebih luas kepada konsep dan makna legal service dibandingkan dengan konsep dan tujuan legal aid atau legal assistance. Karena pada konsep dan ide legal service terkandung makna dan tujuan memberi bantuan kepada anggota masyarakat yang operasionalnya bertujuan menghapuskan kenyataan-kenyataan diskriminatif dalam penegakan dan pemberian jasa bantuan antara rakyat miskin yang berpenghasilan kecil dengan masyarakat kaya yang menguasai sumber dana dan posisi kekuasaan.

Dengan pelayanan hukum yang diberikan kepada anggota masyarakat yang memerlukan, dapat diwujudkan kebenaran hukum itu sendiri oleh aparat penegak hukum dengan jalan menghormati setiap hak yang dibenarkan hukum bagi setiap anggota masyarakat tanpa membedakan yang kaya dan miskin. Di samping untuk menegakkan hukum dan penghormatan kepada hak yang diberikan hukum kepada setiap orang, legal service di dalam operasionalnya, lebih cenderung untuk menyelesaikan setiap persengketaan dengan jalan menempuh cara perdamaian.

2M. Yahya Harahap, Pembahasan Permsalahan dan Penerapan KUHAP Penyidikan dan Penuntutan, (Jakarta: Sinar Grafika, 2000) hlm.333

${ }^{3}$ Ibid. 
Dalam tulisan ini akan diperlihatkan masalah bantuan hukum sesuai dengan apa yang dijumpai dalam kaidah hukum positif di Indonesia. Apakah hukum positif kita telah mengenal bantuan hukum, khususnya bantuan hukum bagi mereka yang sedang berhadapan dengan pemeriksaan perkara mulai dari taraf penyidikan sampai ke tingkat proses pemeriksaan peradilan.

Bantuan hukum berhubungan dengan pemeriksaan perkara. Dalam hukum positif dikenal dua fase perkembangan di bidang bantuan hukum dalam perkara-perkara pidana, yaitu: Pertama, bantuan hukum yang dirumuskan dalam pasal $250 \mathrm{HIR}$. Ini tidak berarti ada pembatasan hak terdakwa untuk mendapatkan bantuan hukum, namun HIR hanya memperkenankan bantuan hukum kepada terdakwa dalam proses pemeriksaan persidangan pengadilan. Sedangkan kepada tersangka pada proses tingkat pemeriksaan penyidikan, HIR belum memberi hak untuk mendapatkan bantuan hukum. Demikian juga "kewajiban" bagi pejabat peradilan untuk penunjuk penasihat hukum, hanya terbatas pada tindak pidana yang diancam dengan hukuman mati. Selain tindak pidana yang diancam dengan hukuman mati, tidak kewajiban bagi pengadilan untuk menunjuk penasihat hukum untuk memberikan bantuan hukum kepada terdakwa.

Kedua, Undang-undang Pokok Kekuasaan Kehakiman Nomor 14 Tahun 1970 tentang Pokok-Pokok Kekuasaan Kehakiman, sebagaimana diubah dan ditambah dengan Undang-Undang Nomor 35 tahun 1999 dan dicabut dengan Undang-undang Nomor 4 Tahun 2004 tentang Kekuasaan Kehakiman. Di dalam Undang-undang Pokok Kekuasaan Kehakiman, diatur suatu ketentuan tentang bantuan hukum yang jauh lebih luas dengan apa yang dijumpai dalam HIR. Pada Undang-undang Nomor 14 Tahun 1970 terdapat satu bab yang khusus memuat tentang bantuan hukum, yaitu diatur dalam pasal 35 sampai dengan pasal 38. Pada penjelasan pasal 35 dapat dibaca landasan pemikiran pembuat undang-undang tentang makna bantuan hukum, yang pada pokoknya menentukan bahwa seseorang yang terkena perkara mempunyai hak untuk memperoleh bantuan hukum. Hal tersebut dianggap perlu karena ia wajib diberi perlindungan hukum sewajarnya. Perlu diingat ketentuan pasal 8, di mana seorang tertuduh wajib dianggap tidak bersalah sampai keputusan pengadilan yang menyatakan kesalahannya dan telah 
memperoleh kekuatan yang tetap. Demikian bunyi penjelasan pasal 35 Undang-undang Nomor 14 tahun 1970, yang memberi gagasan bahwa setiap orang yang tersangkut perkara berhak memperoleh bantuan.

Dari Undang-undang Nomor 14 Tahun 1970 tersebut, dapat disimpulkan bahwa hak bagi setiap orang yang tersangkut urusan perkara untuk memperoleh bantuan hukum. Ketentuan ini memperlihatkan bahwa asas bantuan hukum telah diakui sebagai hal yang penting seperti yang dijelaskan pada penjelasan Pasal 35. Akan tetapi Undang-undang Nomor 14 Tahun 1970, belum sampai kepada taraf yang meletakkan asas "wajib" memperoleh bantuan hukum. Ia masih bertaraf "hak" mendapatkan bantuan hukum.

Namun, sekali pun asas memperoleh bantuan hukum bagi orang yang tersangkut perkara baru merupakan hak, tetapi juga hak memperoleh bantuan hukum dalam perkara pidana. Kalau diperhatikan lebih lanjut ketentuan bantuan hukum yang diatur dalam Undang-undang Nomor 14 tahun 1970, ia meliputi bantuan hukum sejak saat dilakukan penangkapan atau penahanan. Tetapi sifat hak memperoleh bantuan hukum pada taraf penangkapan atau penahanan, baru bersifat "hak menghubungi dan meminta bantuan penasihat hukum".

Pasal 38 menentukan bahwa ketentuan-ketentuan dalam pasal 35, 36, dan 37 tersebut di atas diatur lebih lanjut dengan undangundang. Dengan demikian, ketentuan bantuan hukum yang terdapat pada bab VII Undang-undang Nomor 14 tahun 1970, baru merupakan landasan dan asas umum, belum memuat aturan tata cara pelaksanaannya. Ketentuan umum ini terkatung-katung selama lebih kurang sepuluh tahun. Sehingga dalam masa periode yang tak menentu ini, seringkali terjadi saling pertentangan pendapat antara para pemberi bantuan hukum (pengacara, advokat) pada satu pihak dengan para aparat penegak hukum (Polri dan penuntut umum) pada pihak lain. Para penasihat hukum mendesak kepada para instansi penegak hukum untuk memberi hak seperti yang ditegaskan pasal 35 dan 36 Undang-undang Nomor 14 tahun 1970, yakni dapat mengikuti jalannya pemeriksaan tersangka sejak penyidikan. Pada pihak lain instansi penyidik bertahan tidak memperkenankan dengan alasan peraturan pelaksanaan dan tata cara pemberian bantuan hukum yang dimaksud pasal 35 dan 36 belum diatur. 
Akan tetapi dengan adanya aturan umum yang terdapat pada Undang-undang Nomor 14 tahun 1970, telah membawa rangsangan bagi anggota masyarakat, terutama dari kalangan profesi hukum clan perguruan tinggi untuk menuntut dan mengembangkan lembagalembaga bantuan hukum. Gerakan lembaga-lembaga bantuan hukum yang berkembang tadi merupakan aliran yang lebih menitik-beratkan konsep dan program bantuan hukum ke arah pelayanan hukum bagi rakyat miskin yang tidak berpunya dengan jalan memberi bantuan secara cuma-cuma, menyadarkan hak-hak asasi manusia yang buta hukum, yang bertemakan penegakan hukum dan sekaligus penegakan hukum.

Ketentuan pasal-pasal bantuan hukum yang diatur dalam KUHAP merupakan pelaksana daripada aturan umum yang digariskan dalam Undang-undang Pokok Kekuasaan Kehakiman yang terdapat pada Bab VII, pasal 35 sampai dengan pasal 38. Sebagai peraturan pelaksana, pasal-pasal KUHAP merupakan penjabaran dari ketentuan pokok tersebut. Oleh karena itu, landasan dan orientasi pasal-pasal KUHAP tentang bantuan bertitik tolak dari ketentuan pokok yang digariskan pada Undang-undang Nomor 14 tahun 1970.

Seperti halnya pada Undang-undang Nomor 14 tahun 1970, KUHAP tidak begitu jelas memberi definisi bantuan hukum. Tidak dijumpai penjelasan yang membedakan pengertian bantuan hukum seperti apa yang dikembangkan pada negara-negara yang sudah maju. Siapa yang dimaksud dengan penasihat hukum yang berhak memberi bantuan hukum tersebut? Apakah hanya mereka yang tergolong pada kelompok Peradi atau pokrol? Kemudian, apakah arti penasihat hukum yang dimaksud dalam ketentuan ini sama dengan pengertian legal assistance atau legal service, atau legal aid.

Dengan demikian, KUHAP sendiri belum memadai dan belum dekat sekali dengan rakyat yang memerlukan pelayanan bantuan hukum. Bantuan hukum yang diatur dalam KUHAP, lebih dekat kepada mereka yang kaya dan mampu memberi imbalan jasa kepada yang berprofesi sebagai advokat atau pengacara. Supaya bantuan hukum akrab dengan rakyat kecil yang tidak mampu membayar imbalan jasa, harus terdapat suatu ketentuan yang menegaskan adanya "kewajiban hukum" yang bersifat imperatif memberi bantuan hukum kepada setiap anggota masyarakat tanpa kecuali. Sedangkan yang diatur pada pasal 56 KUHAP hanya 
menegaskan hak tersangka atau terdakwa untuk mendapatkan bantuan hukum dari seorang atau lebih penasihat hukum selama dan pada setiap tingkat pemeriksaan. Dengan demikian, bentuk bantuan hukum yang diatur dalam KUHAP masih bersifat diskriminatif antara orang yang kaya dan yang miskin.

Masalah lain dari pengertian bantuan hukum dalam rumusan KUHAP ialah penasihat hukum yang memberi bantuan hukum ialah seseorang yang telah memenuhi syarat yang ditentukan oleh undang-undang. Ketika Undang-undang Nomor 39 Tahun 1999 tentang Hak Asasi Manusia belum lahir tidak berarti jaminan akan hak asasi manusia tidak mendapatkan perlindungan hukum di negara kita. Kendati pula sebagian besar ketentuan-ketentuan hak asasi manusia ada dalam Konstitusi RIS (1949) dan UUD Sementara (1950) tidak terdapat dalam UUD 1945. Ketentuan tentang hak asasi manusia itu dapat ditemukan dalam berbagai perundang-undangan dan hukum positif yang berlaku di negara kita, tidak kalah pentingnya adalah peranan hakim yang melalui putusan-putusannya dalam kasus-kasus kongkrit.

Contoh hukum positif Indonesia yang akan dipergunakan adalah Kitab Undang-undang Hukum Acara Pidana (KUHAP). Dalam penjelasan KUHAP dapat dibaca celaan terhadap HIR (Herziene Inlandsch Reglement) ${ }^{4}$ yang berlaku di Indonesia sampai tahun 1981, sebelum berlakunya KUHAP yaitu tanggal 31 Desember 1981.5 KUHAP yang notabene berdasarkan Pancasila dan Undangundang Dasar 1945 adalah mementingkan pengkhayatan, pengamalan, dan pelaksanaan hak asasi manusia maupun hak serta kewajiban warga negara. Hak warga negara inilah yang utama dibandingkan dengan hak politik dan hak sosial, sebab hanya apabila warga negara ini benar-benar dimiliki oleh para warga negara dan dipertahankan oleh pengadilan, barulah hak politik dan hak sosial mempunyai arti.

Pengertian HAM itu sendiri inheren dipunyai oleh setiap manusia makhluk Tuhan dan merupakan anugerah Tuhan kepada semua hamba-Nya tanpa pandang bulu. Hak asasi manusia adalah

5 Andi Hamzah, Hukum Acara Pidana Indonesia, (Sinar Grafika: Jakarta, 2001) hlm.3

5 Kansil CST., Pengantara Ilmu Hukum dan Tata Hukum Indonesia, (Jakarta: Balai Pustaka,1989) hlm. 440 
demikian melekat pada sifat manusia, sehingga tanpa hak-hak itu kita tidak mungkin mempunyai martabat sebagai manusia. Karena itu pula harus kita nyatakan bahwa HAM itu tidak dapat dicabut dan tidak boleh dilanggar, sebagaimana hal ini telah dijamin oleh sila kedua dari Pancasila yaitu sila Kemanusiaan Yang Adil dan Beradab dengan disemangati oleh sila-sila lainnya dari Pancasila. Karakteristik inilah yang membedakan hak asasi manusia dari hak-hak lainnya yang diberikan oleh peraturan perundang-undangan kita.

Pandangan bahwa penyebutan hak selalu dibarengi dengan adanya kewajiban timbul dari pemahaman yang benar, bahwa hak dan kewajiban itu adalah simetris. Adalah kesimpulan yang keliru bahwa hak dan kewajiban itu berada pada subyek yang sama. Penyebutan hak selalu harus dibarengi dengan pengertian adanya kewajiban. Sebagai contoh bahwa jika seseorang mempunyai sesuatu hak, maka orang lain dalam hal yang sama mempunyai kewajiban yang berhubungan dengan hal yang sama tersebut, demikian pula sebaliknya. Dengan demikian hak asasi manusia termasuk hak warga negara selalu melekat pada manusia dan hanya dapat dimiliki oleh warga negara. Sedangkan kewajiban yang merupakan bagian simetri dari hak warga negara terdapat pada negara, karena hanya negaralah yang mempunyai kekuasaan memelihara dan melindungi hak warga negara tersebut. Karena itu apabila ingin dipergunakan istilah hak dan kewajiban asasi manusia, maka pengertiannya adalah adanya hak pada individu dan adanya kewajiban pada pemerintah. Hak asasi manusia pada individu menimbulkan kewajiban pada pemerintah untuk melindungi individu tersebut terhadap setiap kemungkinan pelanggaran, termasuk pelanggaran dari negara atau aparat pemerintahan sendiri.

Diundangkannya hukum acara pidana nasional pada akhir tahun 1981 sangat melegakan hati dan memberi harapan baru bagi terwujudnya cita-cita dalam bidang keadilan hukum. KUHAP sebagai landasan hukum peradilan pidana, membawa konsekuensi bahwa alat negara penegak hukum dalam menjalankan tugasnya dituntut untuk meninggalkan cara lama secara keseluruhan, baik dalam berpikir maupun bersikap tindak, harus sesuai dengan ketentuan undang-undang yang berlaku dan menjunjung tinggi hak asasi manusia, terutama terhadap mereka yang tersangkut dalam peradilan pidana. 
Kendati demikian, aparat penegak hukum adalah manusia biasa, yang tidak terlepas dari perbuatan khilaf dan salah. Penangkapan atau penahanan yang sebetulnya dilakukan dengan tujuan untuk kepentingan pemeriksaan demi tegaknya keadilan dan ketertiban dalam masyarakat, ternyata acapkali dilakukan terhadap orang yang tidak bersalah atau kadang-kadang dilakukan terhadap orang yang tidak bersalah atau kerapkali dilakukan melampaui batas waktu yang telah ditentukan, sehingga tersangka atau terdakwa menderita lahir bathin akibat sikap tindak para aparat penegak hukum tersebut. Sudah tentu ini merupakan pelanggaran terhadap hak asasi manusia.

Untuk menjamin perlindungan hak asasi manusia dan agar para aparat penegak hukum menjalankan tugasnya secara konsekuen, maka KUHAP membentuk suatu lembaga baru yang dinamakan praperadilan. Adapun tujuan dari lembaga baru ini adalah sebagai lembaga yang berwenang untuk melakukan pengawasan bagaimana aparat penegak hukum menjalankan tugas dalam peradilan pidana. Lembaga praperadilan merupakan wewenang baru yang diberikan oleh KUHAP pada pengadilan negeri, adalah merupakan kewenangan pengadilan negeri untuk melakukan pengawasan horizontal terhadap segala tindakan yang berkaitan dengan proses penyidikan dan proses penuntutan perkara pidana yang dilakukan oleh pejabat-pejabat dalam tahap pemeriksaan penyidikan dan atau penuntutan.

Dalam praktik peradilan, kerapkali ditemui beberapa permasalahan yang berkaitan dengan hukum acara pemeriksaan yang harus diterapkan oleh hakim untuk menerima, memeriksa, dan memberikan putusan atas permintaan praperadilan yang diajukan kepadanya mengingat KUHAP sendiri tidak secara tegas menyebutkan hukum acara mana yang harus dipergunakan oleh hakim dalam pemeriksaan di persidangan. Dalam hal pemanggilan para pihak, misalnya Mahkamah Agung menegaskan dipergunakan ketentuan KUHAP, sedangkan dalam praktik pemanggilan dilakukan oleh jurusita. Demikian pula mengenai hukum acara di dalam persidangan, oleh karena para pihak yang tersangkut praperadilan bukannya penuntut umum dan terdakwa atau penggugat dan tergugat, sebagaimana dalam acara pemeriksaan pidana maupun 
perdata, maka terdapat kecenderungan pemeriksaan praperadilan bersifat quasi penggugat dan quasi tergugat.

Munculnya lembaga praperadilan dapat dibaca sebagai perlindungan hak asasi manusia yang merupakan pedoman dalam memahami dan menafsirkan arti hak asasi manusia. Mengenai desain prosedur dari KUHAP, dapat ditafsirkan bahwa maksud pembuat undang-undang adalah memberi peran utama kepada pengadilan atau sidang pengadilan. Hal ini didasarkan antara lain pada ketentuan KUHAP pasal 191 dan pasal 197 yang menentukan bahwa baik dalam putusan bersalah maupun putusan bebas hal ini harus didasarkan pada fakta dan keadaan serta alat pembuktian yang diperoleh dari pemeriksaan di sidang.

Dapat dibayangkan bagaimana suatu masyarakat yang dihadapkan pada krisis peningkatan kriminilitas atau pelanggaran hukum pidana tertentu ataupun dikejutkan dengan terjadinya suatu tindak pidana, dapat menghadapi tersangka dengan kemarahan moral yang besar. Dalam keadaan seperti proses penyidikan, penuntut dan pemidanaan dianggap sebagai tidak mempunyai permasalahan hukum. Dalam keadaan ini begitu mudah seorang tersangka, seorang warga negara, tanpa melalui prosedur hukum yang adil berubah status hukumnya menjadi penjahat dan musuh masyarakat.

KUHAP tidak menghendaki suatu proses peradilan di mana seorang tersangka sudah dijatuhi putusan bersalah sebelum prosesnya dimulai, dalam hal ini disebut sebagai eigenrichting. ${ }^{6}$ Apa yang ingin diganti oleh bangsa Indonesia dari HIR melalui KUHAP, proses pembentukan KUHAP menunjukkan bahwa yang ingin diperjuangkan adalah pemahaman untuk melihat proses peradilan pidana itu sebagai berlandaskan proses hukum yang adil, di mana hak-hak tersangka/terdakwa/terpidana dilindungi dan dianggap sebagai bagian hak-hak warga negara dan karena itu bagian dari hak asasi manusia. KUHAP telah merepsi prinsip accusatior, ${ }^{7}$ bahwa dalam acara pidana, penuntut umum dan terdakwa berhadapan sebagai pihak yang sama haknya, untuk melakukan pertarungan

6Sudikno Mertokusuno, Hukum Acara Perdata Indonesia, (Yogyakarta : Liberty, 1988,) hlm.2

7Van Apeldoorn, Pengantar Ilmu Hukum, (Jakarta : Pradnya Paramita, 2001), hlm.338 
hukum di depan hakim yang tidak memihak. Pertimbangan pertama dari KUHAP bahwa negara Republik Indonesia adalah negara hukum berdasarkan Pancasila dan Undang-undang Dasar 1945 yang menjunjung tinggi hak asasi manusia serta yang menjamin segala warga negara bersamaan kedudukannya di dalam hukum.

Lembaga praperadilan yang tertuang dalam KUHAP telah benar-benar mendudukkan posisi tersangka/terdakwa sederajad terhadap penuntut umum. Tidak ada lagi alasan bagi penyidik ataupun penuntut umum untuk memperlakukan tersangka/terdakwa secara semena-mena. Para penegak hukum tersebut harus melakukan penegakan hukum, baik di tingkat penyidikan, penuntutan ataupun tingkat pemeriksaan di pengadilan harus benar-benar sesuai dengan ketentuan yang telah ditetapkan dalam KUHAP. Demikian, bagi pihak korban yang merasa sakit hati atas perlakuan tersangka/terdakwa, diberikan hak yang sama pula untuk mewujudkan perasaannya bilamana terhadap perkara yang telah ia laporkan ternyata hilang demikian saja tanpa bekas. Upaya hukum tersebut diberikan kepada korban, baik di tingkat penyidikan ataupun penuntutan.

Sebagaimana diuraikan di atas bahwa salah satu hak tersangka adalah hak untuk mendapat bantuan hukum dari penasihat hukum selama dalam waktu dan pada setiap tingkat pemeriksaan. Kewajiban untuk memberikan hak seseorang guna mendapatkan bantuan hukum itu mempunyai arti yang sangat penting karena tingkat pengetahuan dan kesadaran masyarakat di bidang hukum masih belum memadai. Seorang tersangka yang ditangkap dan ditahan kebanyakan tidak mengetahui bahwa ia mempunyai suatu hak untuk mendapatkan bantuan hukum, bilamana hak ini tidak diberikan maka selama proses penyidikan ia akan membela dirinya sendiri dengan segala keterbatasannya. Kewajiban yang demikian sudah ditetapkan dalam KUHAP yang menentukan bahwa seorang pemeriksa sebelum melakukan pemeriksaan wajib untuk memberitahukan hak tersebut kepada tersangka. Hal ini dalam praktik acapkali bersifat sebaliknya, di mana terhadap seorang tersangka yang mengetahui akan haknya untuk mendapatkan bantuan hukum diperlakukan sedemikian rupa sehingga ia tidak menggunakan haknya tersebut. 
Hubungan yang langsung antara seorang pemberi bantuan hukum dengan seorang tersangka adalah mutlak perlu untuk kelancaran pemberian bantuan hukum itu sendiri. Demikian juga dengan mendampingi secara fisik dalam setiap tahapan pemeriksaan diperlukan untuk membantu tersangka menghadapi pemeriksaannya demi menjamin obyektifitas pemeriksaan, bukan sebaliknya sebagaimana disinyalir oleh sementara pemeriksa bahwa kehadiran seorang penasihat hukum atau advokad secara fisik terutama dalam tahap pemeriksaan dalam penyidikan bukannya memperlancar akan tetapi justru menghambat jalannya pemeriksaan. Hal ini tentunya tidak akan terjadi jika masing-masing pihak mengetahui status serta perannya dengan baik, serta adanya kesamaan dalam tindakan dan perlakuan pada saat pemberian bantuan hukum kepada tersangka pelaku tindak pidana sehingga faktor subyektifitas dalam perlakuan pemeriksaan terhadap tersangka dapat dihindari.

\section{Kedudukan Advokat selaku Penasihat hukum dalam Proses Penyidikan}

Sejarah hukum di Indonesia merupakan peninggalan kolonial Belanda. Pada waktu itu, peraturan dan perundang-undangan begitu banyak. Oleh karena itu, pada akhirnya dibuatlah peraturan umum mengenai perundang-undangan. Untuk Indonesia (Algemene Bepalingen Van Wetgeving Voor Indonesia) Staatsblad 1847 Nomor 23 yang diumumkan pada tanggal 30 April 1847.8 Inilah Dasar-dasar dan pokok-pokok hukum di Indonesia yang menganut "sistem hukum Eropa Kontinental" yang pada akhir-akhir ini masyarakat hukum kurang memperhatikannya, bahkan cenderung melupakannya.

Indonesia memperoleh kemerdekaan tahun 1945 dengan Undang-undang Dasar yang bersifat singkat dan supel, yaitu hanya memuat 37 Pasal; sedangkan pasal-pasal lainnya hanya memuat Peralihan dan Tambahan. Aturan Peralihan Undang-undang Dasar 1945, Pasal II menyebutkan "segala badan negara dan peraturan yang ada masih langsung berlaku, selama belum diadakan yang baru menurut Undang-Undang Dasar ini.

Kita mengetahui bahwa keadilan yang hakiki sulit dicapai. Kendati demikian dalam kehidupan sehari-hari kita harus selalu

8 Kansil C.S.T., Pengantar Ilmu Hukum, hlm.49 
mencoba secara maksimal untuk mencapainya. Sebagai suatu negara hukum yang berdasarkan konstitusi kita tentunya mendambakan bahwa segala aspek kehidupan di dalam masyarakat dapat diatur dengan undang-undang dan persoalan-persoalan yang timbul dapat diselesaikan secara hukum baik melalui pengadilan, arbitrase maupun melalui negosiasi dan mediasi atau yang sekarang lebih dikenal dengan istilah alternative dispute resolution, sehingga semua persoalan diharapkan dapat diselesaikan secara adil berdasarkan landasan hukum yang menyertainya.

Untuk mencapai keadilan tersebut hanya dimungkinkan jika para penegak hukum telah siap mental dan dapat bersikap profesional untuk melaksanakannya. Sebagaimana diketahui bahwa para penegak hukum di Indonesia belum semuanya dapat bersikap profesional sehingga mengakibatkan tersendat-sendatnya penegakan hukum di negara kita. Berbagai peristiwa telah menandai tersendatsendatnya penegakan hukum seperti kasus Gandhi Memorial School, kaburnya Edy Tansil dari Lembaga Pemasyarakatan Cipinang, hakim dilempari sepatu di Pengadilan Negeri Jakarta Pusat, advokat dipukuli massa di Pengadilan Negeri Bekasi, pemeriksaan ulang perkara Marsinah di Pengadilan Negeri Surabaya, dan contoh-contoh peristiwa lain. Di sisi lain tidak semua persoalan harus diselesaikan melalui badan peradilan, persoalan-persoalan dapat diselesaikan baik melalui pengadilan maupun diselesaikan di luar pengadilan. Untuk itu, peran para penegak hukum sangatlah vital di dalam, konteks suatu negara hukum.

Seringkali anggota masyarakat yang mengalami masalah atau problem tidak sadar bahwa untuk memecahkan masalah tersebut diperlukan jasa seorang advokat dan biasanya kalau dia menyadarinya persoalan itu sudah menjadi rumit, jarang sekali anggota masyarakat berkonsultasi kepada seorang advokat, terkecuali diketahuinya secara pasti alasan mengapa dia harus datang kepada seorang advokat dan minta jasa seorang advokat. Oleh karena itu, di dalam memenuhi kebutuhan akan jasa advokat dari masyarakat diperlukan beberapa kualifikasi yang memadai agar seorang advokat dapat memenuhi kebutuhan masyarakat tersebut. Kebutuhan akan jasa hukum dari seorang advokat dapat berupa nasehat hukum, konsultasi hukum, pendapat hukum, legal audit, pembelaan baik di luar maupun di dalam pengadilan serta. pendampingan di dalam 
perkara-perkara pidana atau tidak menutup kemungkinan dalam arbitrase perdagangan dan perburuhan.

Alternatif penyelesaian sengketa dalam rangka memasuki era perdagangan bebas, kebutuhan akan jasa advokat khusus advokat yang bergerak di bidang hukum bisnis, investment law, cross-border acquisition dan merger sedemikian meningkat. Sehingga dunia bisnis membutuhkan dan menuntut kualitas advokat yang lebih profesional dan berwawasan internaonal. Kita mengenal advokat yang bergerak di bidang hukum bisnis sebagai apa. yang menamakan dirinya konsultan hukum. Perkembangan akan kebutuhan konsultan hukum bisnis adalah suatu kenyataan sebagai akibat dari perkembangan zaman. Persoalannya sekarang adalah apakah konsultan hukum ini termasuk dalam profesi advokat ataukah akan dipisahkan sebagai profesi tersendiri. Ada yang berpendapat bahwa konsultan hukum. bukanlah suatu profesi yang notabene sebenarnya pekerjaan tersebut sudah termasuk dalam profesi advokat sebagaimana dapat dilihat dari definisi "advocate" menurut Black's Law Dictionary. ${ }^{9}$

Selain itu, kenyataan di negara kita sudah lama berpraktik pengacara praktek yang menamakan dirinya pada jaman kolonial sebagai procureur dan pertanyaannya sekarang apakah pekerjaan procureur akan diatur sendiri dan diawasi oleh organisasi tersendiri. Adapun advokat itu sendiri harus kualifikatif dan mempunyai karakter substantif, yaitu ia harus merupakan seorang diplomat dan inovatif dan dapat dipercaya. Tentunya, kualitas tersebut akan merupakan suatu yang sangat ampuh bagi seorang advokat dan dapat dikatakan bahwa seorang advokat dibentuk oleh kondisi dan karakteristik yang demikian itu. Masyarakat tentunya sangat membutuhkan advokat dengan kualitas dan hal ini dapat dijaga dan diawasi oleh suatu asosiasi advokat yang berwibawa dan berani.

Suatu standar profesi hukum yang memenuhi karakteristik dan kualffikasi seperti di atas, hal yang tidak kalah penting adalah terjaminnya independensi profesi advokat. Karena. tanpa adanya independensi profesi, seorang advokat akan sulit membela kliennya dengan baik. Pengawasan terhadap advokat itu paling ideal kalau ada organisasi asosiasi advokat yang kuat dan berwibawa di mana semua pengawasan anggota dan putusan serta sanksi terhadap anggota yang

${ }^{9}$ Ropaun Rambe, Teknik Praktek Advokat, (Jakarta : Gramedia, Jakarta, 2001) hlm.11 
melanggar kode etik advokat dapat mengikat anggotanya dan didengar oleh birokrasi.

Dalam pada itu, kedudukan hakim di dalam sistem hukum belum dijamin, demikian pula belum adanya kebebasan profesi advokat sebagai komplimen terhadap independensi badan peradilan telah menyebabkan penegakan hukum (law enforcement) di negara kita belum berjalan semestinya sehingga pencapaian rule of law menjadi tersendat-sendat. Sementara cita-cita demokrasi dan penegakan hak asasi manusia baru bisa dicapai kalau terdapat rule of law. Apa yang terjadi sekarang adalah penyelesaian masalah acapkali dilakukan secara politis ataupun melalui jalur kekuasaan ketimbang diselesaikan melalui pengadilan secara. hukum.

Selain karakteristik dan kualitas advokat, yang diperlukan oleh masyarakat juga integritas seorang advokat dalam menjalankan tugasnya. Termasuk di dalamnya pengawasan terhadap dirinya (disciplinary supervision) khususnya tentang perilaku dan hubungannya dengan kliennya karena tanpa adanya pengawasan asosiasi advokat maka di dalam tugasnya dapat terjadi perbuatan atau sikap, yang menyimpang dari pada hakekat dari profesi advokat yang notabene sangat diperlukan masyarakat. Pengawasan terhadap profesi advokat ini dan segala tingkah laku dan sikapnya tidak cukup dilakukan oleh birokrasi tetapi sebaiknya diselenggarakan oleh organisasi profesi yang menaungi dan mengawasi perilaku dan sikap advokat. Untuk itu, diperlukan suatu perangkat peraturan atau etika profesi untuk mengatur perilaku dan sikap, yang korektif dari seorang advokat sebagaimana halnya juga etika profesi mengatur hubungan antara advokat dengan kliennya, hubungan dengan rekannya, hubungan dengan pengadilan, martabat advokat, imunitas advokat, bagaimana seorang advokat harus berpraktik, honor advokat, bagaimana menyelesaikan pelanggaran kode etik dan kualifikasi serta syarat untuk menjadi advokat.

Ketentuan hukum yang berkaitan dengan kedudukan advokat dalam proses penyidikan hanyalah dijelaskan dalam pasal 50 hingga pasal 74 KUHAP. Di mana dalam ketentuan tersebut memberikan hak kepada tersangka guna diperlakukan sama dalam proses penegakan hukum. Hal ini bersesuaian dengan adanya asas equality before the law, bahwa setiap orang bersamaan kedudukannya dalam hukum dan pemerintahan. Pasal 50 KUHAP berkenaan dengan hak 
tersangka atas hak tersangka guna memperoleh pemeriksaan untuk diadili sesegera mungkin. Hal ini bersesuaian dengan pasal 4 ayat 2 Undang-undang Nomor 4 Tahun 2004 tentang kekuasaan kehakiman. Hak tersangka sebagaimana tersebut dalam pasal 50 hingga pasal 74 KUHAP dimaksud akan terselenggara dengan baik, bilamana dibantu oleh advokat selaku penasihat hukum. Untuk itu kedudukan seorang advokat adalah salah satu pilar dari sisi hak-hak tersangka dalam rangka proses law enforcement. Seorang advokat harus benar-benar melakukan pembelaan sesuai dengan hak-hak tersangka sebagaimana diatur dalam undang-undang. Sebab di sisi lain tersangka akan diserang semaksimal mungkin oleh jaksa penuntut umum guna dijerat sebagai pelaku tindak pidana berdasarkan hasil pemeriksaan BAP (Berita Acara Pemeriksaan) penyidik.

Adapun hakim sebagai catur wangsa terakhir akan mengadili berdasar pembuktian yang diajukan oleh Penuntut umum dan pembelaan advokat selaku Penasihat hukum. Sehingga proses peradilan tersebut sesungguhnya adalah benar-benar berimbang, mengingat hak tersangka dalam proses penyidikan hingga persidangan selalu memperoleh bantuan hukum dan advokat. Sejak awal dari proses penyidikan, tersangka didampingi oleh penasihat hukum. Pada saat tahap penuntutan, terdakwa juga mendapat bantuan hukum dari penasihat hukum. Tahap terakhir dalam pemeriksaan persidanganpun terdakwa juga mendapatkan bantuan hukum, sehingga posisi hakim adalah mempertimbangkan pembuktian penuntut umum dan pembelaan penasihat hukumnya.

Dengan demikian kedudukan advokat selaku penasihat hukum dalam proses law enforcement tidak dibenarkan ambigu (mendua), ia hanya bertugas untuk melakukan pembelaan sesuai dengan ketentuan perundang-undangan yang berlaku. Pembelaan penasihat hukum terhadap terdakwa terlepas kepada terbukti tidaknya kesalahan terdakwa, Sehingga yang dimaksud dengan law enforcement dalam konteks pembelaan tersangka/terdakwa, pada posisi advokat selaku penasihat hukum tidak dibenarkan membantu penyidik ataupun penuntut umum. Artinya ketika hak-hak tersangka telah diberikan secara penuh tidak terkecuali bantuan hukum dari advokat, maka hakim tidak akan setengah hati untuk menjatuhkan hukuman sesuai dengan berat ringannya kesalahan tersangka/terdakwa. 


\section{Hak atas Bantuan Hukum pada Tersangka dan Akibat Hukum terhadap BAP}

Menyimak dari pemahaman pasal 56 ayat (1) KUHAP yang di dalamnya menegaskan hak dari tersangka atau terdakwa didampingi penasihat hukum apabila tindak pidana yang disangkakan atau didakwakan diancam dengan pidana mati atau ancaman pidana 15 tahun atau lebih, atau bagi yang tidak mampu yang diancam pidana 5 tahun atau lebih yang tidak mempunyai penasihat hukum sendiri, di mana Pejabat yang bersangkutan dalam proses peradilan wajib menunjuk Penasihat hukum bagi mereka. Di mana ketentuan pasal 56 ayat (1) KUHAP dipandang dari pendekatan strict law atau formalitas legal thinking mengandung beberapa aspek permasalahan hukum, antara lain :

1. Mengandung aspek nilai Hak Asasi Manusia (HAM), di mana bagi setiap tersangka atau terdakwa berhak didampingi Penasihat hukum pada semua tingkat pemeriksaan dalam proses peradilan. Hak ini tentu sejalan dan/atau tidak boleh bertentangan dengan "deklarasi universal" yang menegaskan hadirnya Penasihat hukum untuk mendampingi tersangka atau terdakwa merupakan sesuatu yang inherent pada diri manusia, dan konsekuensi logisnya bagi penegak hukum yang mengabaikan hak ini adalah bertentangan dengan nilai HAM.

2. Pemenuhan hak ini oleh penegak hukum dalam proses peradilan pada semua tingkat pemeriksaan menjadi kewajiban dari pejabat yang bersangkutan apabila tindak pidana yang disangkakan atau didakwakan :

a. Diancam dengan pidana mati atau 15 ( limabelas ) tahun lebih, atau

b. Bagi yang tidak mampu yang diancam dengan pidana 5 (lima) tahun atau lebih yang tidak mempunyai penasihat hukum sendiri.

Jika kedua syarat di atas terpenuhi, maka pejabat yang bersangkutan pada semua tingkat pemeriksaan dalam proses peradilan wajib menunjuk penasihat hukum bagi mereka. Berdasarkan ketentuan pasal 56 ayat (1) KUHAP ini tentu kehadiran dan keberadaan penasihat hukum mendampingi tersangka bersifat imperatif, sehingga mengabaikannya 
mengakibatkan hasil pemeriksaan atau hasil penyidikan tidak sah atau batal demi hukum.

3. Pasal 56 ayat (1) KUHAP sebagai ketentuan yang bernilai HAM telah diangkat menjadi salah satu patokan Miranda Rule atau Miranda Principle. ${ }^{10}$ Apabila pemeriksaan/penyidikan, penuntutan atau pemeriksaan perkara tersangka/ terdakwa di persidangan tidak didampingi penasihat hukum maka sesuai dengan Miranda Rule, hasil penyidikan tidak sah (illegal) atau batal demi hukum (null and void). Standar Miranda Rule inilah yang ditegakkan dalam putusan Mahkamah Agung No. 1565 K/Pid/1991, tanggal 16 September 1993 yang menyatakan "apabila syarat-syarat permintaan dan atau hak tersangka/terdakwa tidak terpenuhi seperti halnya penyidik tidak menunjuk penasihat hukum bagi tersangka sejak awal penyidikan, tuntutan penuntut umum dinyatakan tidak dapat diterima ".

Berdasarkan uraian di atas jika dikaitkan dengan Miranda Rule seperti dimaksud dalam pasal 56 ayat (1) KUHAP dapat disimpulkan sebagai berikut :

1. Dalam tindak pidana yang disangkakan atau didakwakan kepada tersangka/terdakwa harus diancam dengan pidana mati atau 15 (lima belas) tahun atau lebih atau yang tidak mampu diancam dengan pidana 5 (lima) tahun atau lebih yang tidak punya Penasihat hukum sendiri, maka pada semua tingkat pemeriksaan dalam proses peradilan harus didampingi penasihat hukum;

2. Apabila tersangka/terdakwa tidak mampu menyediakan penasihat hukum sendiri, pejabat yang bersangkutan pada setiap tingkat pemeriksaan dalam proses peradilan dibebani kewajiban untuk menunjuk penasihat hukum bagi tersangka/terdakwa tersebut. Pemeriksaan penyidikan yang tersangkanya tidak didampingi penasihat hukum, sesuai dengan kerangka pasal $115 \mathrm{KUHAP}$, maka hasil pemeriksaan penyidikan tersebut adalah tidak sah atau batal demi hukum, karena bertentangan dengan hukum acara (undue process);

${ }^{10}$ M. Yahya Harahap, Op.Cit., h.328 
Demikian gambaran sekilas penerapan yang harus ditegakkan dari sudut formalistic legal thinking tentang Miranda Rule yang telah diadopsi ke dalam pasal 56 ayat (1) KUHAP. Perlu diketahui tujuan pokok yang ingin dicapai atas penegakan Miranda Rule dalam proses peradilan seperti dimaksud dalam pasal 56 ayat (1) KUHAP adalah agar terjamin pemeriksaan yang fair dan manusiawi terhadap diri tersangka/terdakwa, sebab dengan hadirnya penasihat hukum mendampingi tersangka sejak dari proses penyidikan di tingkat kepolisian dimaksudkan dapat berperan melakukan kontrol, sehingga pemeriksaan terhindar dari penyiksaan, pemaksaan dan kekejaman. Namun jika dipandang dari sudut pendekatan berdasarkan kepentingan umum (public interest) tentu akan berbeda dan bahkan selamanya cenderung berbeda atau cenderung pula berbenturan. Untuk mengatasi hal itu peran dan kemampuan Hakim saat memutuskan perkara sangat penting dan menentukan dalam melihat perlunya, keseimbangan dalam penegakan hukum yang menyangkut antara kepentingan hak asasi manusia yang bersifat individual dengan kepentingan umum (public interest) yang berorientasi pada perlunya ada, rasa aman dan ketertiban di tengah-tengah masyarakat.

Sejalan dengan salah satu tujuan utama dari hukum pidana itu sendiri, dan kita semua tahu bahwa hukum pidana merupakan hukum publik yang bersifat imperatif yang mengatur perilaku individu dan masyarakat tentang perbuatan mana yang boleh dilakukan dan perbuatan mana yang tidak boleh dilakukan dengan disertai pemberian sanksi yang tegas bagi siapa yang melanggarnya. Di mana pelaksanaan hukum tersebut dapat dipaksakan kepada semua subyek hukum dengan maksud agar tercipta suasana yang kondusif dalam tata hubungan antar individu dalam masyarakat agar tercipta kehidupan bermasyarakat, berbangsa dan bernegara yang teratur, tertib dan aman.

Pelanggaran Miranda Rule dalam praktik peradilan dapat terjadi pada semua tingkat pemeriksaan dalam proses peradilan mulai dari tingkat penyidikan oleh pihak kepolisian selaku penyidik, proses penuntutan di kejaksaan selaku penuntut umum dan oleh pihak pengadilan selaku pemeriksa dan pemutus perkara yang bersangkutan. Pasal 56 ayat (1) KUHAP telah mewajibkan kepada pejabat yang bersangkutan untuk menunjuk penasihat hukum bagi 
tersangka/terdakwa pada semua tingkat pemeriksaan dalam proses peradilan.

Adapun pengertian "pejabat yang bersangkutan" dalam pasal 56 ayat (1) KUHAP adalah pejabat dalam lingkup pengertian dari The Criminal Justice System yang dimulai dari proses penangkapan, penahanan, penyidikan, penuntutan dan pemeriksaan perkara di sidang pengadilan terhadap diri tersangka dan/atau terdakwa, jadi di sini yang dimaksud pejabat yang bersangkutan adalah: (a) Pejabat selaku penyidik di kepolisian; (b) pejabat selaku jaksa/penuntut umum di kejaksaan negeri dalam hal ini adalah Kepala Kejaksaan Negeri; dan (c) pejabat pengadilan di mana perkara terdakwa diperiksa dan diputuskan, dalam hal ini adalah Ketua Pengadilan.

Dengan satu pengertian penyidik wajib menunjuk penasihat hukum ketika tersangka ada dalam proses penyidikan dan demi hukum dan batas kewenangan yang dimiliki surat penunjukan penasihat hukum tersebut dengan sendirinya berakhir jika penyidikan tidak diperlukan lagi terhadap diri persangka, kemudian setelah perkaranya dilimpahkan ke kejaksaan (P.21) jaksa/penuntut umum dalam hal ini Kepala Kejaksaan Negeri wajib pula menunjuk penasihat hukum bagi tersangka/terdakwa, hal ini dimaksudkan siapa tahu oleh pihak jaksa/penuntut umum masih diperlukan pemeriksaan tambahan terhadap diri tersangka yang perlu didampingi Penasihat hukum, dan selanjutnya demi hukum dan batas kewenangan yang dimiliki Surat Penunjukan Penasihat hukum tersebut dengan sendirinya berakhir pula jika berkas perkara telah dilimpahkan ke pengadilan. Kemudian pejabat pengadilan bersangkutan dalam hal ini Ketua Pengadilan wajib pula menunjuk penasihat hukum bagi terdakwa, begitu seterusnya jika terdakwa masih melakukan upaya hukum terhadap putusan pengadilan negeri berupa banding dan kasasi. Kewajiban pejabat yang bersangkutan untuk menunjuk penasihat hukum pada suatu tingkat pemeriksaan dalam proses peradilan tersebut tidak berlaku/gugur dalam: (1) Sebelum pemeriksaan dimulai, tersangka/terdakwa telah mempunyai penasihat hukum sendiri yang telah ia tunjuk sendiri atau atas tunjukan dari keluarga tersangka tersebut; (2) tersangka atau terdakwa tersebut diancam dengan pidana penjara kurang dari 5 (lima) tahun. 
Sedangkan jika sudah terjadi penunjukan penasihat hukum oleh pejabat yang bersangkutan, surat penunjukan tersebut dapat berakhir bila: (1) Pemeriksaan terhadap tersangka/terdakwa tersebut telah selesai, sehingga dengan sendirinya Surat Penunjukan tersebut telah berakhir; (2) Setelah adanya penunjukan penasihat hukum oleh pejabat yang berwenang, misalnya kepada. penasihat hukum A, namun tersangka/terdakwa dan/atau keluarganya menunjuk sendiri penasihat hukum B untuk mendampingi tersangka/terdakwa tersebut; (3) ketika penasihat hukum melakukan pendampingan terhadap tersangka yang didasarkan Ssrat penunjukan dari penyidik di sana telah terjadi hubungan hukum secara langsung antara tersangka dengan penasihat hukum yaitu dalam bentuk telah ditandatanganinya surat kuasa khusus dari tersangka kepada penasihat hukum bersangkutan sehingga pada saat surat kuasa khusus dari tersangka diterima oleh penasihat hukum, maka surat penunjukan yang dimiliki penasihat hukum dari penyidik seketika itu berakhir selanjutnya pejabat di kejaksaan dan pejabat di pengadilan tidak wajib lagi menunjuk penasihat hukum bagi terdakwa;

Ketika penasihat hukum akan melakukan pendampingan terhadap diri tersangka yang didasarkan surat penunjukan dari penyidik, ternyata tersangka menolak untuk didampingi penasihat hukum, maka penyidik membuat berita acara dan/atau membuat surat pernyataan dari tersangka yang bersangkutan yang isinya tersangka menolak adanya penasihat hukum dalam perkara yang dihadapinya dan surat pernyataan penolakan dari tersangka tersebut diketahui dan turut ditandatangani oleh penasihat hukum yang bersangkutan. Konsekuensinya keberadaan berita acara atau surat pernyataan tersebut yang dilampirkan dalam berkas perkara yang bersangkutan menghapuskan kewajiban pejabat yang bersangkutan untuk menunjuk penasihat hukum bagi terdakwa, maka pejabat kejaksaan dan pejabat pengadilan tidak perlu lagi menunjuk Penasihat hukum bagi tersangka/terdakwa bersangkutan kecuali jika yang bersangkutan memintanya.

\section{Penutup}

Dari uraian pembahasan di atas penulis dapat menyimpulkan bahwa: Pertama, kedudukan advokat selaku penasihat hukum dalam proses penyidikan adalah memposisikan dirinya sebagai wakil dari 
tersangka dalam rangka memperoleh hak-haknya. Baik hak atas praduga tidak bersalah (presumption of innocent), hak atas perlakuan yang sama di depan hukum (equality before the law), hak atas memperoleh peradilan yang cepat, sederhana dan biaya ringan, hak atas persidangan di muka umum, hak atas memperoleh bantuan hukum, hak atas pemberitahuan tentang alasan dilakukan penyidikan, hak untuk memberikan keterangan secara bebas tanpa tekanan atau paksaan, dan sebagainya. Advokat selaku penasihat hukum tersangka tidak dibenarkan berpihak kepada jaksa selaku penuntut umum. Hal ini dikarenakan proses penegakan hukum (law enforcement) telah dilakukan secara berimbang antara penuntut atau korban dengan yang dituntut yaitu tersangka. Sejak proses penyidikan korban diwakili oleh penyidik yaitu polisi atau jaksa, sedang tersangka didampingi oleh advokat selaku penasihat hukumnya. Kemudian pada tingkat penuntutan, korban diwakili oleh jaksa selaku penuntut umum, sedangkan terdakwa diwakili oleh advokat selaku penasihat hukum. Adapun pada tingkat pemeriksaan di depan persidangan pengadilan, tersangka didampingi oleh advokat selaku penasihat hukum dan korban diwakili oleh jaksa selaku penuntut umum. Dengan demikian fakta hukum yang dikemukakan di depan hakim selaku pejabat yang mempunyai kewenangan untuk mempertimbangkan dan memutuskan adalah berasal dari Jaksa selaku pihak yang menuntut dan dari advokat selaku pihak yang membela terdakwa. Artinya terdapat keseimbangan kepentingan korban sebagai pihak yang dirugikan dan kepentingan terdakwa sebagai pihak yang menimbulkan kerugian. Konsekuensi yuridis yang lahir terhadap kedudukan advokat selaku penasihat hukum adalah ia harus memperjuangkan seluruh hak-hak tersangka/terdakwa sesuai dengan undang-undang yang berlaku.

Kedua, sebagai konsekuensi yuridis atas kedudukan advokat dalam proses penyidikan tersebut, maka akibat hukum terhadap BAP yang telah dibuat tanpa kehadiran penasihat hukum menurut pasal 56 ayat 1 KUHAP tersebut adalah batal demi hukum. Hal ini dikarenakan, bilamana bantuan hukum tidak diberikan terhadap tersangka yang berhak memperoleh bantuan hukum, akan diperoleh kedudukan yang timpang atau berat sebelah antara posisi korban yang diwakili oleh penyidik di tingkat penyidikan dan tersangka yang tidak didampingi oleh penasihat hukum. Sehingga tersangka 
tidak akan memperoleh hak-hak secara optimal, hal ini akan berpengaruh terhadap proses penyidikannya. Demikian juga dalam tingkat penuntutan, korban diwakili oleh jaksa selaku penuntut umum, sedangkan terdakwa tidak didampingi oleh penasihat hukum. Hal ini melahirkan proses penuntutan yang tidak berimbang, sehingga terdakwa berada dalam posisi yang lemah. Hasil dari proses hukum, baik di tingkat penyidikan ataupun penuntutan yang notabene berat sebelah akan melahirkan pertimbangan hakim yang berat sebelah pula. Karenanya adalah logis jika konsekuensi hukum terhadap penyidikan tersangka yang tidak diberikan hak untuk memperoleh bantuan hukum dinyatakan batal demi hukum.

\section{Daftar Pustaka}

Apeldoorn, Van. Pengantar Ilmu Hukum, Cet.XXIX. Jakarta: Pradnya Paramita, 2001.

Hamzah, Andi. Hukum Acara Pidana Indonesia, Cet.I. Jakarta: Sinar Grafika, 2001

Harahap, M. Yahya. Pembahasan Permsalahan dan Penerapan KUHAP Penyidikan dan Penuntutan, Cet.I. Jakarta: Sinar Grafika, 2000

Kansil CST. Pengantara Ilmu Hukum dan Tata Hukum Indonesia, Cet.VIII. Jakarta: Balai Pustaka, 1989

Makarao, Mohammad Taufik dan Suhasril. Hukum Acara Pidana dalam Teori dan Praktek, Cet.I. Jakarta: Ghalia Indonesia, 2004.

Mertokusuno, Sudikno. Hukum Acara Perdata Indonesia, Cet.I. Yogyakarta: Liberty, 1988

Rambe, Ropaun. Teknik Praktek Advokat, Cet.I. Jakarta: Gramedia, 2001

Winarta, Frans Hendra. Advokat Indonesia Citra, Idealisme dan Keprihatinan, Cet.I. Jakarta: Pustaka Sinar Harapan, 1995 